\title{
Induction of Systemic Resistance in Barley Leaves by Pruning of Organs against Powdery Mildew Fungus*
}

\author{
Masatoshi Fujiwara**, Hachiro OKU**, Tomonori ShIRAISHI** \\ and Seiji Ouchi**
}

\begin{abstract}
The effect of pruning of organs on the induction of the systemic resistance in barley seedling against powdery mildew fungus was investigated. Pruning of leaves, root, and remaining albumen of barley seedling induced resistance in the remaining leaves against the infection of powdery mildew fungus. The resistance was induced within $2 \mathrm{hr}$ after pruning of organs and continued at least for $6 \mathrm{hr}$, in some cases for $120 \mathrm{hr}$. The pruning of organs did not reduce the hyphal growth of the challenger. The pruning of root system with hypocotyl did not induce resistance, but induced rather susceptibility in the primary leaf.
\end{abstract}

(Received December 12, 1985)

Key words: induced resistance, systemic resistance, barley, Erysiphe graminis, pruning of organs.

\section{Introduction}

Immunization or vaccination is one of the most effective tools for the control of infectious diseases in mammals. There seems to be reports of immunization of plant at least 100 years $\mathrm{ago}^{8}$. Recently, scientists have revived attention to plant immunization to clarify the molecular mechanism and also to control diseases. The detailed works of this field have been done by Kuć and his coworkers and reviewed by Kuć(,9).

Several plants were known to be protected systemically by inoculation of a part of plant with incompatible $e^{2,3,6,13)}$ or compatible ${ }^{2,4,11)}$ plant pathogens. In cucurbits, the systemic resistance against anthracnose fungus could be induced by localized inoculation with Colletotrichum lagenarium ${ }^{11}$ and tobacco necrosis virus ${ }^{6,10)}$, but was not induced by mechanical injury and injuries caused by dry ice, chemicals, or fungal and plant extracts $^{6,11)}$. In contrast, injuring tomato roots with hot water, toxic compounds, and periodic root pruning ${ }^{1,7)}$, or hot water treatment of whole plant at $47-52 \mathrm{C}$ for $30 \mathrm{sec}^{11}$ reduced the severity of Fusarium wilt.

Inoculation of lower leaf of barley with both incompatible or compatible powdery mildew fungus induced resistance in upper leaves against the infection by the compatible powdery mildew fungus ${ }^{4,5,12}$. These phenomena involve two possibilities; one is that

* Supported in part by a Grant from the Ministry of Education, Science and Culture of Japan (No. 60304022).

** College of Agriculture, Okayama University, Okayama 700, Japan 䫆山大学農学部

Present address of the last author: Faculty of Agriculture, Kinki University, Higashiosaka, Osaka

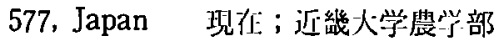


the signal (inducer of resistance) is originated from inducer fungus, and the other is that the mechanical injury made by the inducer fungus during the penetration of host epidermis elicit the signal.

To elucidate the mechanism of induced systemic resistance in barley powdery mildew disease, the effect of injury, "pruning of organs" on the induction of systemic resistance was studied. This paper reports these results.

\section{Materials and Methods}

Plant material. A barley (Hordeum vulgare L.) cultivar, H. E. S. 4 was used. Seeds of this cultivar were soaked in tap water overnight and germinated on the wet filter paper in a Petri dish. Germinated seeds of a uniform size were sown in vermiculite in a plastic pot of $8 \mathrm{~cm}$-diameter and grown in a growth chamber at $22 \pm 2 \mathrm{C}$ under the artificial illumination (ca. 20,000 lux, $12 \mathrm{hr} /$ day). The seedlings of which secondary leaf was just developing were used for experiment.

Fungal material. Erysiphe graminis DC. f. sp. hordei Marchal race Hh4 was cultured on seedlings of barley cultivar H.E.S. 4 which were grown under the above conditions. For synchronization of the inoculum, leaves of 12-14 day-old seedlings were inoculated with fresh conidia, and allowed to grow for 8-9 days in a growth chamber of artificial illumination (ca. 3,000 lux, $12 \mathrm{hr} /$ day) at $22 \mathrm{C}$. The old conidial chains were blown away, and fresh conidia emerged during subsequent $12 \mathrm{hr}$ were used as inocula.

Induction of systemic resistance by pruning of organs. Primary-, secondary leaf, root, root with remaining albumen, or root with hypocotyl was pruned and the remaining organs were incubated at $22 \mathrm{C}$ under the artificial illumination of 3,000 lux for appropriate time.

Evaluation of induced-systemic resistance. The primary-or secondary leaf to be tested for the induced-systemic resistance was excised and the cut-end was moistened with wet absorbent cotton. These leaves were laid on the absorbent cotton in a plastic container $(30 \times 22 \times 5 \mathrm{~cm})$. Leaves were covered with glass slides leaving the area of 5-7 $\mathrm{cm}$ from the cut-end, and this area was challenged by conidia suspension of race $\mathrm{Hh}$ 4 in perfluorotributylamine by spraying. The inoculum size on leaves was adjusted to be ca. 10 conidia per microscopic view $(\times 150)$.

The inoculated leaves were kept in a moist chamber by wrapping the container with plastic film, and the fungus was allowed to infect leaves for $48 \mathrm{hr}$ at $22 \mathrm{C}$. Then leaves were fixed with ethanol, stained with lactophenol cotton blue and the infection frequency was estimated under a microscope. The infection frequency was calculated as follows :

Infection frequency $=\frac{\text { Number of conidia elongating secondary hyphae }}{\text { Number of conidia forming appressoria }} \times 100$.

The length of the secondary hyphae of the challenger was also measured under a microscope with a micrometer.

\section{Results}


The effect of periodic leaf pruning on the infection frequency of the remaining leaves was examined.

The pruning of the primary leaf induced resistance in the secondary leaf. Minimum time needed for resistance induction was within $2 \mathrm{hr}$, and the effect of pruning continued at least for $120 \mathrm{hr}$ (Fig. 1).

The effect of periodic pruning of the primary leaf on the length of the secondary hyphae of the challenger formed on the secondary leaf was shown in Table 1. No significant difference was observed between the length of the secondary hyphae formed on control and protected leaves.

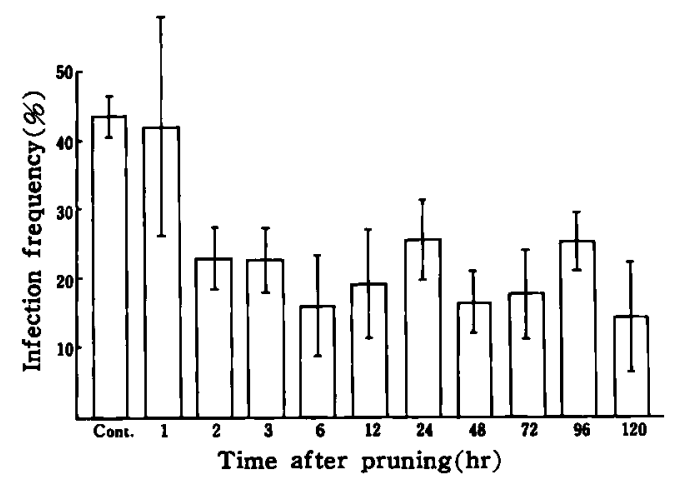

Fig. 1. Induction of systemic resistance in secondary leaf of barley seedling by periodic pruning of primary leaf against infection by powdery mildew fungus.

Vertical bars indicate standard deviation.

Table 1. Effect of periodic pruning of primary leaf of barley seedling on growth of secondary hyphae of challenger formed on secondary leaf

\begin{tabular}{c|c}
\hline $\begin{array}{c}\text { Time after pruning } \\
(\mathrm{hr})\end{array}$ & $\begin{array}{c}\text { Length of secondary hyphae } \\
\text { of challenger }(\boldsymbol{\mu m})^{\mathrm{a})}\end{array}$ \\
\hline 0 (Control) & $358 \pm 57.7$ \\
1 & $379 \pm 21.0$ \\
2 & $394 \pm 42.0$ \\
3 & $324 \pm 61.6$ \\
6 & $304 \pm 18.8$ \\
12 & $381 \pm 37.7$ \\
24 & $319 \pm 43.1$ \\
48 & $376 \pm 28.4$ \\
72 & $347 \pm 15.2$ \\
96 & $345 \pm 55.8$ \\
120 & $342 \pm 12.7$ \\
\hline
\end{tabular}

a) Mean with standard deviation. Length of the secondary hyphae was measured $48 \mathrm{hr}$ after inoculation. 
The pruning of the secondary leaf also induced systemic resistance in the remaining primary leaf $1.5 \mathrm{hr}$ later (Fig. 2). In this case, the induced resistance disappeared 12 hr later.

Systemic resistance induced by periodic pruning of root

The pruning of root system induced resistance to infection both in primary and secondary leaves $1.5 \mathrm{hr}$ after pruning. The induced-systemic resistance continued at least for $24 \mathrm{hr}$ (Fig. 3).

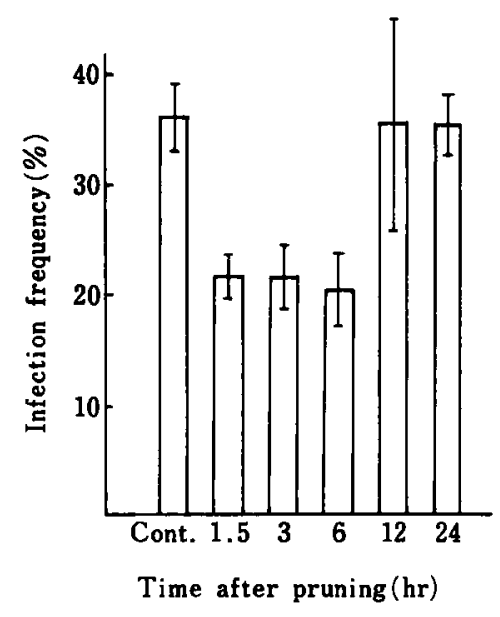

Fig. 2. Induction of systemic resistance in primary leaf of barley seedling by periodic pruning of secondary leaf against infection by powdery mildew fungus. Vertical bars indicate standard deviation.

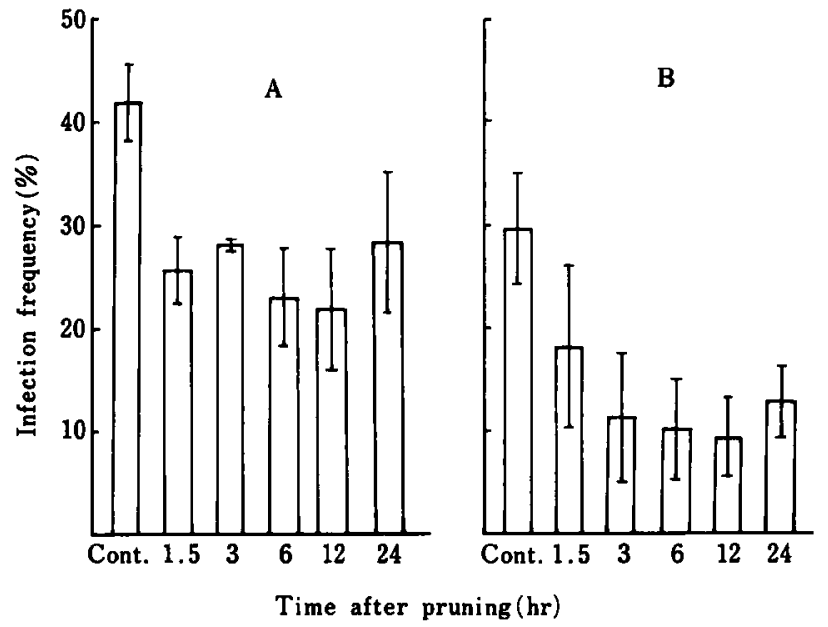

Fig. 3. Induction of systemic resistance in leaves of barley seedling by periodic pruning of root against infection by powdery mildew fungus. A: Primary leaf, B: Secondary leaf. Vertical bars indicate standard deviation.

No significant difference was also found between the length of the secondary hyphae of the challenger formed on control and protected leaves.

\section{Systemic resistance induced by pruning of the other organs}

The pruning of the primary-, secondary leaf or root system induced systemic resistance in the remaining leaves against the infection by powdery mildew fungus $2 \mathrm{hr}$ after pruning and the resistance continued at least for $24 \mathrm{hr}$. Therefore, the effect of pruning of various organs on the infection of the subsequent inoculation with the challenger was examined $6 \mathrm{hr}$ after pruning.

As shown in Fig. 4, the infection frequency in the primary leaf reduced significantly by pruning of root, remaining albumen or remaining albumen with root, but not by pruning root with hypocotyl and coleoptile. Therefore, the effect of the periodic pruning of root with hypocotyl on the induction of resistance in primary and secondary leaves was examined.

As shown in Fig. 5, no apparent resistance was induced by pruning of organs including hypocotyl and root. In the primary leaf, the pruning induced apparently the susceptibility. 


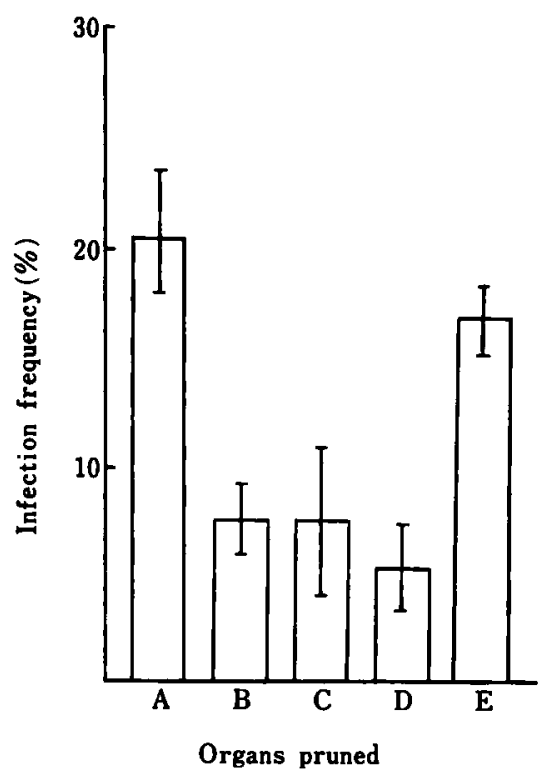

Fig. 4. Effect of pruning of various organs of barley seedling on infection frequency of powdery mildew fungus on secondary leaf.

A: Control, B: Remaining albumen was pruned, C: Root was pruned, D: Remaining albumen and root were pruned, E: Root, hypocotyl and coleotpile were pruned. Challenger was inoculated $6 \mathrm{hr}$ after pruning. Vertical bars indicate standard deviation

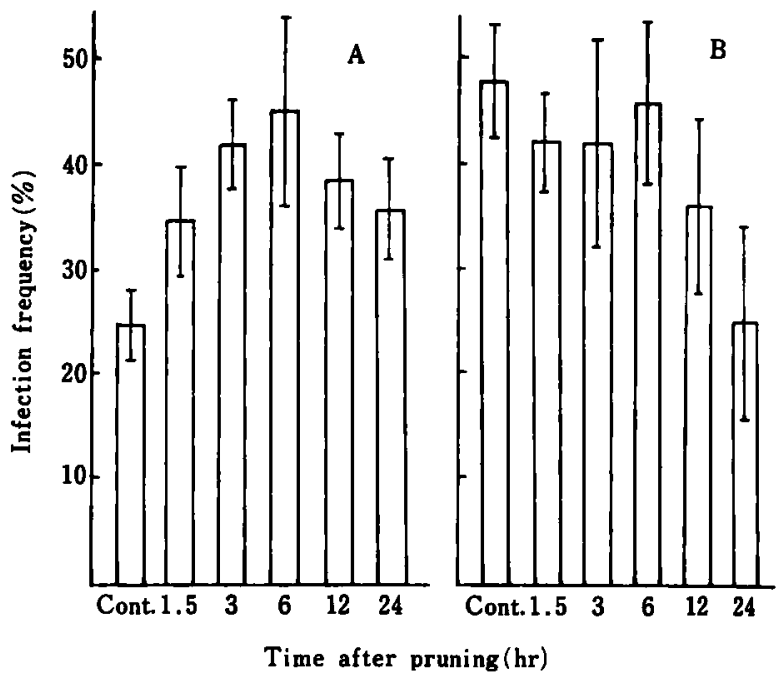

Fig. 5. Effect of periodic pruning of root with hypocotyl of barley seedling on the infection frequency of powdery mildew fungus on primary and secondary leaves.

A: Primary leaf, B: Secondary leaf, Vertical bars indicate standard deviation.

\section{Discussion}

Pruning of the primary leaf induced in the secondary leaf of barley seedling resistance to infection by powdery mildew fungus. Pruning of the secondary leaf induced also resistance in the primary leaf. Thus no direction was found in the transmission of the signal responsible for induced-systemic resistance. The pruning of root and the remaining albumen also induced resistance. The resistance was induced very rapidly after pruning, within $2 \mathrm{hr}$, and continued at least $6 \mathrm{hr}$.

The fact that the pruning of root with hypocotyl induced no more resistance suggested the importance of the hypocotyl in the induction of systemic resistance. The hypocotyl may play a role in the transfer of the signal to the remaining leaves. In the primary leaf, a susceptibility was induced apparently in all experiments of periodic pruning of root with hypocotyl. This result also suggest the possibility of the importance of hypocotyl in maintaining the resistance in this host-parasite combination.

Inoculation of the primary leaf with powdery mildew fungus induced resistance in upper leaves not only against the infection but also against the growth of the secondary 
hyphae ${ }^{5,12)}$ and the colony production ${ }^{5)}$ of the challenger. However, the pruning of organs did not affect the growth of the secondary hyphae. One possibility for this inconsistency might result from the difference of the mechanism of induced resistance between by fungal inoculation and by pruning of organs. The other possibility is that the constant stimulus is needed for the limitation of the hyphal growth though the signals for resistance produced by inoculation and pruning are the same. If the latter assumption is acceptable, the signal is originated from host plant by the mechanical injury even in the induced resistance by fungal inoculation.

Financial supprot from Sankyo Co., Ltd., Tokyo is acknowledged.

\section{Literature cited}

1. Anchisi, M., Gennari, M. and Matta, A. (1985). Physiol. Pl. Path. $26: 175-183$.

2. Cruickshank, I. A. M. and Mandryk, M. (1960). J. Austral. Inst. Agric. Sci. 26: 369-372.

3. Elliston, J., Kuć, J. and Williams, E. (1971). Phytopathology $61: 1110-1112$.

4. Fujiwara, M., Ouchi, S. and Oku, H. (1985). Ann. Phyotpath. Soc. Japan $51: 376$ (Abstr.).

5. Hwang, B. K. and Heitefuss, R. (1982). Phytopath. Z. $103: 41-47$.

6. Jenns, A. E. and Kuć, J. (1977). Physiol. Pl. Path. $11: 202-212$.

7. Keyworth, W. G. and Dimond, A. E. (1952). Phytopathology $42: 311-315$.

8. Kuć, J. (1982). Bio Science $32: 854-860$.

9. Kuć, J. (1982). In Plant Infection (Asada, Y., Bushnell, W. R. Ouchi, S. and Vance, C. P. eds.) Japan Scientific Soc. Press and Springer-Verlag, Tokyo and Berlin. pp.137-155.

10. Kuć, J. and Richmond, S. (1976). Phytopathology $67: 533-536$.

11. Kuć, J. Shockley, G. and Kerney, K. (1975). Physiol. Pl. Path. $7:$ 195-199.

12. Ouchi, S., Konishi, H. and Oku, H. (1984). Ann. Phytopath. Soc. Japan $50: 126$ (Abstr.).

13. Ross, A. F. (1964). Phytopathology $54: 1436$ (Abstr.).

\section{和 文 摘 要}

藤原將寿・奥 八郎・白石友紀・大内成志 : オオムギ苗の器官切除によるうどんこ病に対する全身抵抗性の 誘導について

オオムギ苗の第 1 葉を切除すると第 2 葉に, 第 2 葉を切除すると第 1 葉に, 根や根部に残存する肧乳を切除 すると, 第 1 ，第 2 葉にうどんて病菌の感染に対する抵抗性が誘導される。抵抗性は切除 2 時間以内に誘導さ れ, 少くとも 6 時間, 長い場合には120時間以上持続する。器官の切除は, 接種菌の菌系の生長には影響を与 えない。根と共に肧軸を切除すると, 抵抗性は誘導されず, 第 1 茶ではむしろ感受性が誘導されるので, オオ ムギ苗におけるうどんこ病菌に対する誘導抵抗性や，抵抗性の維持には，肧軸が重要な役割をはたしているむ のと考えられる。 